\title{
HAK KOMUNAL ATAS TANAH SEBAGAI HAK ATAS TANAH DESA PAKRAMAN DI BALI
}

\author{
Oleh \\ Made Oka Cahyadi Wiguna \\ Fakultas Hukum Universitas Pendidikan Nasional (UNDIKNAS) Denpasar \\ Jl. Bedugul No. 39, Sidakarya- Denpasar \\ okacahyadi@undiknas.ac.id
}

\begin{abstract}
The government has indeed provided legal protection and certainty to indigenous peoples regarding their ulayat lands, through a Ministerial Regulation. However, it needs to be studied more deeply about the concept of communal rights to land and Pakraman village as the subject of communal rights holders on land. Communal rights to land are conceptualized as models of land rights that have just been raised in the national land law system. The consequence is that indigenous and tribal peoples as communal rights holders are authorized to use and benefit from their communal land. Pakraman village qualifies as a subject of communal rights to land because Pakraman village in Bali is classified into the community of the community, has a system of customary government referred to as the traditional prajuru led by a customary village leader. Then Pakraman village has a legal area called the Palemahan Pakraman village. As an instrument that regulates the life and social interaction of the community, awig-awig is the customary law of the community in a Pakraman village in Bali.
\end{abstract}

Keywords: Communal Right to Land, Desa Pakraman.

\section{A.PENDAHULUAN}

Pengakuan terhadap eksistensi hak atas tanah adat dari masyarakat hukum adat merupakan suatu hal yang sangat ideal untuk diwujudkan, karena masyarakat hukum adat merupakan bagian dari bangsa Indonesia yang mempunyai hak untuk diakui eksistensinya. Terlebih lagi pasca reformasi, konstitusi Indonesia telah memberikan pengakuan yang representatif guna memberikan perlindungan dan kepastian hukum terhadap kesatuan masyarakat hukkum adat di Indonesia. Sebut saja ketentuan Pasal 18 B ayat (2) Undang-Undang Dasar Negara Republik Indonesia Tahun 1945 (UUD Tahun 1945) memberikan pengakuan bahwa "Negara mengakui dan menghormati kesatuan-kesatuan masyarakat hukum adat beserta hak-hak tradisionalnya sepanjang masih hidup dan sesuai dengan perkembangan masyarakat dan prinsip Negara Kesatuan Repbulik Indonesia, yang diatur dalam undang-undang".

Pengakuan serupa juga diatur dalam Ketetapan Majelis Permusyawaratan Rakyat
Republik Indonesia Nomor IX/MPR/2001 tentang Pembaruan Agraria dan Pengelolaan Sumber Daya Alam (Ketetapan MPR) dengan tegas menginstruksikan kepada negara melalui organorgannya yaitu Dewan Perwakilan Rakyat Republik Indonesia dan Presiden Republik Indonesia untuk melakukan pembaruan agrarian dan pengelolaan sumber daya alam berlandaskan prinsip-prinsip yang telah ditentukan. Salah satunya prinsip yang tertuang dalam Pasal 4 huruf $j$ Ketetapan MPR tersebut, yaitu pembaruan agrarian dan pengelolaan sumber daya alam harus dilaksanakan dengan prinsip "mengakui, menghormati, dan melindungi hak masyarakat hukum adat dan keragaman budaya bangsa atas sumber daya agrarian/sumber daya alam".

Sebelum UUD Tahun 1945 dan Ketetapan MPR memberikan pengakuan terhadap eksistensi masyarakat hukum adat dan hak-hak tradisionalnya, sesungguhnya Undang-Undang Republik Indonesia Nomor 5 Tahun 1960 tentang Peraturan Dasar Pokok-Pokok Agraria yang 
umum dikenal dengan UUPA telah memberikan seklumit pengaturan mengenai hal tersebut. UUPA sebagai payung hukum mengenai keagrariaan diharapkan mampu memberikan pengakuan tersebut.

Nilai tradisional yang terkandung dalam UUPA tidak lain adalah nilai-nilai yang terkandung dalam hukum adat sebagai pranata hukumnya masyarakat hukum adat. Hukum adat itulah yang kemudian menjadi sumber utama dan pelengkap dalam pembangunan hukum tanah nasional. Oleh karena itu, Nurjaya berpandangan bahwa ideologi sentralisme hukum yang menghendaki pranata hukum negara (state law) sebagai satu-satunya hukum yang berlaku dan mengikat semua masyarakat dalam suatu negara tidak dapat diwujudkan di Indonesia (Nurjaya, 2014). Menempatkan hukum adat dalam posisi yang strategis dalam pembangunan hukum tanah nasional sekaligus sesungguhnya merupakan bentuk pengakuan negara terhadap eksistensi masyarakat hukum adat beserta hak-hak tradisionalnya.

Harapan mengenai pengakuan tersebut tertuang dalam ketentuan Pasal 3 UUPA yang mengatur bahwa "dengan mengingat ketentuanketentuan dalam pasal 1 dan 2 pelaksanaan hak ulayat dan hak-hak yang serupa itu dari masyarakat-masyarakat hukum adat, sepanjng menurut kenyataannya masih ada, harus sedemikian rupa sehingga sesuai dengan kepentingan nasional dan negara, yang berdasarkan atas persatuan bangsa serta tidak boleh bertentangan undang-undang dan peraturanperaturan lain yang lebih tinggi". Berdasarkan ketentuan tersebut maka hak-hak masyarakat hukum adat dikonsepkan sebagai hak ulayat. Sebagai ius constitutum mengenai pertanahan, UUPA tidak memberikan penjelasan yang jelas dan tegas mengenai definisi dari hak ulayat tersebut, baik dalam batang tubuh maupun dalam penjelasannya.

Oleh Boedi Harsono hak ulayat kemudian didefinisikan sebagai "serangkaian wewenang dan kewajiban suatu masyarakat hukum adat, yang berhubungan dengan tanah yang terletak dalam lingkungan wilayahnya, yang merupakan pendukung utama penghidupan dan kehidupan masyarakat yang bersangkutan sepanjang masa" (Harsono, 2005:185-186). Atas dasar tersebut dapat ditafsirkan mengenai substansi dari hak ulayat adalah dalam hubungan hukum perdata kaitannya dengan hak bersama masyarakat hukum adat atas tanah dan hukum publik yang terwujud dalam urusan mengelola, mengatur dan memimpin peruntukan, penguasaan, penggunaan dan pemeliharaannya (Harsono, 2005).

Pengakuan yang diberikan oleh ketentuan

Pasal 3 tersebut tentunya masih mengandung kelemahan-kelemahan. Kelemahan mendasar dari pengakuan yang diatur dalam ketentuan tersebut diantaranya adalah mengenai substansi dari hak ulayat tidak disebutkan secara tegas dan jelas dan kepastian hukum mengenai bukti dari keberadaan hak ulayat tersebut juga belum diatur. Kelemahankelemahan tersebut, sesungguhnya menjadi akar dari terjadinya banyak sengketa tanah adat yang melibatkan masyarakat hukum adat dengan pihak swasta dan/atau pemerintah, bahkan dapat terjadi sengketa antar masyarakat hukum adat itu sendiri. Oleh karena itulah, Menteri Agraria/Kepala Badan Pertanahan Nasional kemudian menerbitkan Peraturan Menteri Negara Agraria/Kepala Badan Pertanahan Nasional Nomor 5 Tahun 1999 tentang Pedoman Penyelesaian Masalah Hak Ulayat Masyarakat Hukum Adat. Peraturan menteri ini diharapkan menjadi solusi dari berbagai permasalahan yang terjadi akibat minimnya pengakuan dan perlindungan serta kepastian hukum terhadap hak ulayat masyarakat hukum adat.

Peraturan menteri tersebut memang telah memberikan definisi mengenai hak ulayat dan tanah ulayat. Akan tetapi, pokok persoalan dari berbagai permasalahan yang ada tidak hanya mengenai pengaturan definisi. Sesungguhnya pokok persoalan mengenai hak ualayat dan termasuk di dalamnya tanah ulayat adalah mengenai kepastian hukum mengenai hak atas tanah tersebut. Jika dikomparasikan dengan jaminan kepastian hukum mengenai hak-hak atas tanah yang diatur dalam UUPA, maka jaminan kepastian hukum bertujuan untuk memudahkan bagi pemegang hak membuktikan diri sebagai pemegang hak yang tertentu. Jaminan kepastian hukum tersebut antara lain adalah kepastian status hak atas tanahnya, kepastian subjek dan objek hak atas tanah (Santoso, 2010). Untuk mendapatkan kepastian hukum seperti yang dimaksud, maka hak atas tanah harus didaftarkan berdasarkan ketentuan peraturan perundang-undangan yang berlaku. Pendaftaran hak ulayat merupakan pokok persoalan yang menjadi akar dari banyaknya terjadi sengketa-sengketa tanah adat di Indonesia. Sehingga keberadaan tanah-tanah ulayat di seluruh Indonesia belum mendapatkan perlindungan dan kepastian hukum yang cukup. Kelemahan pada aspek pendaftaran tanah ulayat juga terjadi terhadap tanah-tanah ulayat di Bali sebagai hak tradisional masyarakat hukum adat. Bali sebagai salah satu daerah di Indonesia yang eksistensi masyarakat hukum adatnya masih tetap terjaga sampai saat ini, sangat membutuhkan pengakuan dan perlindungan hukum yang lebih representatif saat ini. Mengingat dalam wilayah adat di Bali terbagi ke dalam desa-desa adat yang lebih dikenal dengan desa pakraman dan tersebar di seluruh wilayah Provinsi Bali yang mempunyai tanah-tanah ulayat. 
Pada realitas kehidupan masyarakat hukum adat di Bali, terdapat beberapa jenis tanah ulayat di Bali. Dharmayuda berpandangan bahwa tanah ulayat di Bali terbagi ke dalam beberapa jenis, yaitu (Dharmayuda, 1987) :

1. Tanah desa atau tanah druwe desa atau tanah druwe merupakan tanah-tanah yang dikuasai langsung oleh desa pakraman, seperti tanah pasar, tanah lapang, tanah kuburan dan tanah bukti (tanah sawah atau ladang yang diberikan kepada pejabat desa atau perangkat desa);

2. Tanah Laba Pura merupakan tanah yang diperuntukkan sebagai tempat untuk membangun Pura dan tanah yang digunakan untuk membiayai kelangsungan upacara secara rutin dan untuk pembiayaan perawatan dan pemugaran Pura;

3. Tanah Pekarangan Desa (Tanah PKD) dikuasai oleh desa pakraman yang kemudian diserahkan penggunaannya kepada krama desa pakraman (warga desa) untuk mendirikan tempat tinggal dengan luas tertentu dan hampir sama untuk tiap keluarga dari krama desa ;

4. Tanah Ayahan Desa adalah tanah yang dikuasai oleh desa pakraman akan tetapi penggarapannya diserahkan kepada krama desa pakraman (warga) dengan hak menikmati hasil disertai dengan kewajiban (ayahan) yang dapat berupa tenaga maupun materi tertentu.

Tanah ayahan desa atau dengan sebutan lainnya di masing-masing desa pakraman yang substansinya adalah sama sesuai dengan pengertian di atas maka itulah yang sesungguhnya menjadi bagian dari hak ulayat masyrakat hukum adat di Bali sebagaimana disebutkan dalam ketentuan Pasal 3 UUPA yang dikelola oleh desa pakraman. Pengelolaan hak tersebut akan semakin kuat dan baik, apabila didukung dengan adanya pengakuan dari negara. Oleh karena pada kenyataannya di Bali, penguasaan tanah-tanah ulayat oleh desa pakraman di Bali telah berlangsung dalam kurun waktu yang sangat lama dan dilaksanakan secara turun temurun berdasarkan hukum adat setempat. Kemudian tanah-tanah ulayat tersebut merupakan lebensraum dari masyarakat hukum adat di Bali. Sehingga sangat layak kemudian pemerintah memberikan perlindungan dan jaminan kepastian hukum yang representatif melalui peraturan perundang-undangan agar tanah dapat memberikan sebesar-besarnya kemakmuran rakyat.

Pada perkembangannya untuk segera memberikan perlindungan dan kepastian hukum kepada masyarakat hukum adat mengenai tanahtanah ulayatnya, maka pemerintah kemudian mengundangkan Peraturan Menteri Agraria dan Tata Ruang/Kepala Badan Pertanahan Nasional Nomor 10 Tahun 2016 tentang Tata Cara
Penetapan Hak Komunal Atas Tanah Masyarakat Hukum Adat dan Masyarakat Yang Berada Dalam Kawasan Tertentu yang selanjutnya dalam tulisan ini disebut Peraturan Menteri. Oleh karena itu penulis berpandangan perlu untuk dikaji lebih mendalam mengenai desa pakraman sebagai subjek dari hak komunal atas tanah serta konsep hak komunal atas tanah masyarakat hukum adat di Bali dengan tajuk Era Baru Pengakuan Hak Komunal Atas Tanah Desa Pakraman di Bali. Adapun permasalahan yang akan dikaji secara komperehensif dalam kajian konseptual ini adalah:

1. Bagaimana sesungguhnya konsep hak komunal atas tanah masyarakat hukum adat?

2. Apakah desa pakraman di Bali merupakan masyarakat hukum adat sebagai subjek pemegang hak atas tanah komunal ?

\section{B. PEMBAHASAN \\ 1. Konsep Hak Komunal Atas Tanah Masyarakat Hukum Adat}

Isu mengenai pengakuan dan perlindungan hukum terhadap hak atas tanah masyarakat hukum adat memang terus menjadi perhatian, karena eksistensinya sejauh ini masih tetap terjaga. Keberadaan tanah-tanah adat tersebut sejatinya mempunyai kedudukan yang penting bagi kelangsungan kehidupan masyarakat hukum adat. Mandala berpendapat bahwa bagi masyarakat hukum adat di Bali, pembahasan mengenai tanah secara otomatis juga membahas mengenai eksistensi diri, karena terdapat adanya hubunganhubungan sosioreligius (Mandala, 2011). Terdapat suatu pandangan bahwa antara manusia dan tanah dalam hukum adat terdapat suatu pertalian hukum yang didasarkan pada pandangan participerend denken atau alam pikiran yang serba berpasangan. Sehingga dalam kehidupannya manusia tidak dapat lepas dari tanah karena, tanah sebagai tempat tinggal bagi keluarga dan masyarakat, tempat untuk mencari kehidupan, sebagai tempat peristirahatan terakhir bagi anggota keluarga yang meninggal dan adanya kepercayaan sebagai tempat tinggal dewa-dewa pelindung dan bersemayamnya roh-roh leluhur (Dharmayuda, 2001).

Diskursus mengenai eksistensi tanah adat, sesungguhnya tidak dapat dipisahkan terhadap eksistensi dari masyarakat hukum adatnya. Hal tersebut disebabkan karena tanah-tanah adat tersebut ada dalam eksistensi wilayah hukum adat dari suatu masyarakat hukum adat. Oka Cahyadi menyebutkan seperti misalnya eksistensi tanah adat di Bali, secara internal akan sangat bergantung dari eksistensi dari desa pakraman sebagai masyarakat hukum adat dan secara eksternal eksistensinya akan sangat tergantung dari pengakuan hukum negara (Wiguna, 2016). Minimnya pengakuan dari hukum negara mengenai hal tersebut harus segera 
dicarikan solusinya, karena dapat saja menimbulkan permasalahan lanjutan akibat ketidakpastian hukum.

Padahal menurut Ni'Matul Huda, negara dan pemerintah mempunyai peran untuk mengantarkan seluruh rakyatnya menuju ke titik kesejahteraan, karena negara sebagai lembaga sosial memang diadakan guna memenuhi kebutuhan-kebutuhan seluruh rakyatnya (Huda, 2015). Dengan demikian, negara dan melalui pemerintah wajib memenuhi kebutuhan mengenai pengakuan dan perlindungan tanah-tanah adat dari masyarakat hukum adat yang merupakan bagian dari bangsa Indonesia.

Pengakuan dan perlindungan yang dimaksudkan dalam konteks di atas adalah adanya tindakan-tindakan nyata yang dilakukan oleh negara. Sebagai negara hukum, tentunya tindakan nyata yang diperlukan adalah melalui pembentukan hukum yang mengarah kepada pengakuan dan perlindungan hukum. Hayatul Ismi memberikan pandangannya mengenai pengakuan negara atas eksistensi masyarakatnya yaitu, pengakuan negara terhadap penguasaan masyarakat hukum adat atas tanah adatnya dilakukan dengan pengakuan baik secara politik maupun hukum negara melalui pengaturan hak dan kewajiban negara atau pemerintah memberikan penghormatan, kesempatan dan perlindungan guna berkembangnya masyarakat hukum adat itu sendiri berikut pula hak-hak tradisional yang dimiliki (Ismi, 2012).

Solusi mengenai pengakuan dan perlindungan hukum tanah adat yang dimiliki oleh masyarakat hukum adat, nampaknya menemukan titik terang ketika negara melalui pemerintah, mengatur mengenai pengakuan dan perlindungan tanah adat tersebut dalam peraturan menteri. Peraturan menteri tentang Hak Komunal Atas tanah mengkonsepkan hak atas tanah adat sebagai hak komunal atau hak pemilikan bersama oleh masyarakat hukum adat. Ketentuan Pasal 1 angka 1 Peraturan Menteri tersebut mengartikan "hak komunal atas tanah adalah hak milik bersama atas tanah suatu masyarakat hukum adat atau hak milik bersama atas tanah yang diberikan kepada masyarakat yang berada dalam kawasan tertentu". Berdasarkan ketentuan tersebut dapat dipahami bahwa hak komunal tersebut menjadi hak pemilikan bersama bagi seluruh anggota masyarakat hukum adat.

Oleh karena itu, sesungguhnya Hak komunal ini dikonsepkan sebagai model hak atas tanah yang baru dimunculkan dalam sistem hukum tanah nasional. Seperti yang disebutkan dalam ketentuan Pasal ayat (1) Peraturan Menteri bahwa "Masyarakat hukum adat yang memenuhi persyaratan dapat dikukuhkan hak atas tanahnya". Kemudian dilanjutkan pada ketentuan Pasal 3 ayat
(1) "hak atas tanah diberikan dalam bentuk hak komunal". Urip Santoso, berpandangan bahwa "hak atas tanah adalah hak yang memberikan wewenang kepada pemegang haknya untuk menggunakan tanah atau mengambil manfaat dari tanah yang dihakinya"(Santoso, 2010:82). Secara historis Tara Wiguna berpendapat bahwa, hak atas tanah masyarakat hukum adat tersebut mempunyai akibat ke dalam berupa pengaturan sampai dengan memberikan kesempatan kepada warganya untuk mengelola tanah. Disamping itu hak atas tanah tersebut juga berakibat ke luar yaitu mengatur orang yang bukan warganya atau orang luar kelompoknya yang mempunyai keinginan memanfaatkan tanah adat tersebut atas ijin masyarakat hukum adat dan membayar upeti (Wiguna, 2009).

Berdasarkan hal tersebut, maka secara bersama-sama masyarakat hukum adat sebagai pemegang hak komunal atas tanah mempunyai kewenangan untuk menggunakan tanahnya untuk keperluan membangun pasar, balai desa, kantor, rumah dan pendirian bangunan lainnya yang berkaitan untuk kepentingan masyarakat hukum adat, serta dapat diambil manfaatnya untuk keperluan pertanian, perkebunan dan peternakan. Akan tetapi, penggunaan dan pemanfaatan tanah komunal tersebut tidak dapat dilepaskan dari ketentuan-ketentuan hukum adat yang berlaku di wilayah tersebut. Disamping itu, pemanfaatan dan penggunaan hak komunal atas tanah yang telah didaftarkan, dapat dikerjasamakan dengan pihak ketiga. Tentunya hal tersebut, sesuai dengan kesepakatan yang nantinya disepakati oleh masyarakat hukum adat.

Diterbitkannya peraturan menteri mengenai hak komunal atas tanah, merupakan satu bentuk politik hukum yang ditempuh oleh pemerintah guna memberikan pengakuan dan perlindungan hukum yang lebih konkret terhadap hak atas tanah masyarakat hukum adat. Terdapat dua pandangan mengenai lingkup dari politik hukum tersebut, yaitu pandangan politik hukum sebagai kebijakan mengenai penciptaan, pembaharuan dan pengembangan hukum dan pandangan yang menyebutkan bahwa politik hukum terkait dengan pelaksanaan hukum itu sendiri (Rosadi \& Desmon, 2013). Abdul latif dan Hasbi Ali mengutarakan pandangannya mengenai apa sesungguhnya politik hukum tersebut, yaitu "bagian dari ilmu hukum yang menelaah perubahan ketentuan hukum yang berlaku dengan memilih dan menentukan ketentuan hukum tentang tujuan beserta cara dan sarananya untuk mencapai tujuan tersebut dalam memenuhi perubahan kehidupan masyarakat sebagai hukum yang dicita-citakan (ius constituendum)" (Latif \& Ali, 2010).

Masyarakat hukum adat sangat membutuhkan pengakuan dan perlindungan hukum 
terhadap hak atas tanah-tanah adatnya. Pengakuan hak komunal atas tanah yang di atur dalam peraturan menteri sesungguhnya merupakan hukum yang dicita-citakan agar kebutuhan bagi masyarakat hukum adat terpenuhi sesuai dengan perkembangan kehidupan zaman yang sangat membutuhkan kepastian hukum. Hal tersebut merupakan suatu kebijakan hukum yang bertujuan memenuhi kebutuhan pranata hukum yang memberikan kepastian hukum terhadap tanahtanah adat dan masyarakat hukum adat. Adapun cara yang digunakan adalah dengan memberikan peluang bagi hak atas tanah masyarakat hukum adat sebagai nilai-nilai yang hidup dalam masyarakat, untuk didaftarkan dalam bentuk hak komunal atas tanah. Mengakomodasi nilai-nilai yang hidup dalam masyarakat menurut Imam Syaukani dan Ahsin Thohari, merupakan salah satu agenda yang ditekankan dalam politik hukum nasional (Syaukani \& Thohari, 2013).

Dalam rangka membangun politik hukum nasional dalam bidang keagrariaan, memang sangat dibutuhkan hukum yang bersifat responsif yang dapat merespon kebutuhan-kebutuhan masyarakat termasuk pengakuan dan perlindungan hukum terhadap hak atas tanah masyarakat adat. Mahfud MD berpandangan bahwa "produk hukum responsif merupakan produk hukum yang mencerminkan rasa keadilan dan memenuhi harapan masyarakat. Dalam proses pembuatannya memberikan peranan besar dan partisipasi penuh kelompok-kelompok sosial atau individu di dalam masyarakat. Hasilnya bersifat responsif terhadap tuntutan-tuntutan kelompok sosial atau individu masyarakat" (Mahfud MD, 2012:32).

Dalammenyusun produk hukum mengenai hak atas tanah masyarakat hukum adat yang responsif, proses pembuatannya harus mengundang berbagai kelompok masyarakat hukum adat untuk mendapatkan aspirasi-aspirasi mengenai hal tersebut. Sehingga hasilnya sesuai dengan kehendak dan kebutuhan dari masyarakat hukum adat. Sukirno memberikan pandangannya mengenai pengakuan hak ulayat bagi masyarakat hukum adat harus dilakukan secara holistik yaitu dari segi substansial pengakuan tersebut sekaligus pula terhadap hukum adat dan masyarakat hukum adatnya, dan dari aspek prosedural maka pembentukan peraturan perundang-undangan mengenai pengakuan dalam konteks ini, pihak legislatif dan eksekutif harus memahami struktur sosial budaya masyarakat hukum adat dan melibatkan secara aktif masyarakat hukum adat dalam seluruh proses pembentukannya. Sehingga melahirkan peraturan yang memberikan keadilan dan kesejahteraan bagi masyarakat hukum adat (Sukirno, 2018).

Oleh karenanya, dengan peraturan menteri tersebut masyarakat hukum adat berharap banyak bahwa, kepastian hukum terhadap hak atas tanah masyarakat hukum adat dapat diwujudkan. Mengingat peraturan menteri yang diterbitkan oleh pemerintah tersebut, merupakan langkah progresif guna merespon keinginan masyarakat hukum adat untuk mendapatkan pengakuan, perlindungan hukum dan kepastian hukum terhadap tanah-tanah adatnya.

\section{Desa Pakraman Adalah Masyarakat Hukum Adat Subyek Hak Komunal}

Eksistensi masyarakat hukum adat di Indonesia sesungguhnya telah menunjukkan keberadaannya jauh sebelum Indonesia mencapai kemerdekaan. Keberadaan masyarakat hukum adat tersebut merupakan suatu kenyataan yang harus diakui oleh negara. Pengakuan negara terhadap eksistensinya merupakan suatu hal yang wajib dan urgen untuk segera dilakukan, mengingat mereka adalah bagian dari bangsa Indonesia. Hilman Hadikusuma berpandangan bahwa keberadaan masyarakat hukum adat sampai saat ini masih tetap ada dan hidup dengan melandaskan kehidupannya berdasarkan peraturan adatnya masing-masing dalam ikatan territorial maupun genealogis bahkan dapat terjadi percampuran antara kedua model ikatan tersebut (Hadikusuma, 2003).

Masyarakat hukum adat merupakan suatu kesatuan orang perorangan yang menjalankan kehidupan dengan dilandasi rasa kebersamaan pada suatu wilayah tertentu dan mempunyai tatanan kehidupan dalam bentuk aturan hukum yang mengikat secara internal dan lazim disebut dengan hukum adat berikut dengan organ-organ pemerintahan adatnya sendiri. Masyarakat hukum adat mempunyai otonomi dalam mengelola urusan rumah tangga dan harta kekayaannya secara mandiri yang dipercayakan kepada organ-organ pemerintahannya tersebut. Disamping itu, mereka mempunyai wilayah tertentu sebagai ruang kehidupan sekaligus tempat untuk mencari penghidupan bagi dirinya sendiri maupun keluarganya.

Pada awalnya konsep masyarakat hukum adat diawali dengan istilah masyarakat hukum atau persekutuan hukum yang merupakan terjemahan rechtsgemeenschap yang dikemukakan oleh Ter Haar. Tolib setiady berpandangan bahwa masyarakat hukum merupakan "sekelompok orang yang terikat sebagai suatu kesatuan dalam suatu susunan yang teratur, yang bersifat abadi dan memiliki pimpinan serta kekayaan sendiri baik berwujud maupun tidak berwujud dan mendiami atau hidup di wilayah tertentu" (Setiady, 2009:76). Maria Sumardjono dalam pandangannya memberikan ciri-ciri dari masyarakat hukum adat, yaitu : "mereka merupakan suatu kelompok manusia, mempunyai kekayaan tersendiri terlepas 
dari kekayaan perorangan, mempunyai batas wilayah tertentu dan mempunyai kewenangan tertentu" (Sumardjono, 2009:56). Penulis berpandangan bahwa pengaturan mengenai pengelolaan kekayaan, proteksi wilayah dan substansi kewenangan yang dimiliki bukan berarti dijalankan tanpa aturan, keseluruhan mengenai halhal tersebut tentunya diatur dalam hukum adatnya masing-masing.

Lebih lanjut, pada Kongres Masyarakat Adat Nusantara I memberikan definisi mengenai masyarakat adat yaitu "komunitas-komunitas yang hidup berdasarkan asal-usul leluhur secara turun-temurun di atas suatu wilayah adat, yang memiliki kedaulatan atas tanah dan kekayaan alam, kehidupan sosial budaya yang diatur oleh hukum adat, dan lembaga adat yang mengelola keberlangsungan kehidupan masyarakatnya" (Aliansi Masyarakat Adat Nusantara, 2018). Berdasarkan pandanganpandangan di atas dapat dipahami bahwa masyarakat hukum adat mempunyai karakteristik tersendiri yang sekaligus menjadi ciri-ciri pokoknya, yaitu sekelompok orang atau manusia yang mempunyai ikatan secara turun temurun di wilayah tertentu, hidup secara teratur berdasarkan hukum adatnya, mempunyai harta kekayaan yang terpisah dari kekayaan perorangan anggotanya, mempunyai organ-organ penguasa yang mempimpin kehidupan bersama tersebut sekaligus berdaulat atas tanah dan kekayaan alam di wilayah adatnya serta secara otonomi dapat mengatur kehidupan rumah tangganya.

Berbicara mengenai konsep masyarakat hukum adat dalam konteks peraturan perundangundangan, sesungguhnya telah disebutkan dalam berbagai peraturan perundang-undangan. Sebut saja dalam ketentuan Pasal 1 angka 31 UndangUndang Republik Indonesia Nomor 32 Tahun 2009 tentang Perlindungan dan Pengelolaan Lingkungan Hidup yang menyebutkan "masyarakat hukum adat adalah kelompok masyarakat yang secara turun temurun bermukim di wilayah geografis tertentu karena adanya ikatan pada asal usul leluhur, adanya hubungan yang kuat dengan lingkungan hidup, serta adanya sistem nilai yang menentukan pranata ekonomi, politik, sosial, dan hukum".

Kemudian Pasal 1 angka 33 UndangUndang Republik Indonesia Nomor 1 Tahun 2014 tentang Perubahan Atas Undang-Undang Republik Indonesia Nomor 27 Tahun 2007 tentang Pengelolaan Wilayah Pesisir dan Pulau-Pulau Kecil yang menyebutkan bahwa "Masyarakat Hukum Adat adalah sekelompok orang yang secara turuntemurun bermukim di wilayah geografis tertentu di Negara Kesatuan Republik Indonesia karena adanya ikatan pada asal usul leluhur, hubungan yang kuat dengan tanah, wilayah, sumber daya alam, memiliki pranata pemerintahan adat, dan tatanan hukum adat di wilayah adatnya sesuai dengan ketentuan peraturan perundang-undangan.

Berkaitan dengan penetapan hak komunal atas tanah, Peraturan Menteri telah memberikan definisi mengenai masyarakat hukum adat yaitu "sekelompok orang yang terikat oleh tatanan hukum adatnya sebagai warga bersama suatu persekutuan hukum karena kesamaan tempat tinggal ataupun atas dasar keturunan". Kemudian berdasarkan konsep masyarakat hukum adat tersebut, ditetapkanlah bahwa masyarakat hukum adat sebagai subyek pemegang hak komunal atas tanah. Adapun ketentuan mengenai persyaratan masyarakat hukum adat untuk dapat sebagai pemegang hak komunal atas tanah adalah sebagaimana yang disebutkan pada ketentuan Pasal 4 ayat (1) yaitu : "masyarakat masih dalam bentuk paguyuban, ada kelembagaan dalam perangkat penguasa adatnya, ada wilayah hukum adat yang jelas dan ada pranata dan perangkat hukum, yang masih ditaati".

Keberadaan masyarakat hukum adat terdapat hampir di seluruh wilayah Indonesia, Provinsi Bali merupakan salah satu daerah yang secara empirik keberadaan masyarakat hukum adatnya masih nyata keberadaannya. Bahkan eksistensi masyarakat hukum adat di Bali senantiasa hidup, tumbuh dan berkembang dalam kehidupan sosial masyarakatnya. Kesatuan masyarakat hukum adat di Bali lazim disebut dengan desa pakraman. Dalam Pasal 1 angka 4 Peraturan Daerah Provinsi Bali Nomor 03 Tahun 2001 tentang Desa Pakraman diatur bahwa "Desa Pakraman adalah kesatuan masyarakat hukum adat di Provinsi Bali yang mempunyai satu kesatuan tradisi dan tata krama pergaulan hidup masyarakat umat Hindu secara turun temurun dalam ikatan kahyangan tiga atau kahyangan desa yang mempunyai wilayah tertentu dan harta kekayaan sendiri serta berhak mengurus rumah tangganya sendiri". Adapun jumlah desa pakraman sebagai kesatuan masyarakat hukum adat di Bali sampai akhir tahun 2017 berjumlah 1493 desa pakraman (Majelis Utama Desa Pakraman, 2017).

Berdasarkan definisi di atas, maka dapat dipahami bahwa desa pakraman sebagai kesatuan masyarakat hukum adat di Bali yang hidup dalam kebersamaan dalam suatu wilayah tertentu. Masyarakat ini mempunyai ikatan spiritual yang sama yaitu Pura Kahyangan Tiga (Pura di suatu desa pakraman sebagai tempat suci untuk memuja Tuhan dalam manifestasinya sebagai Dewa Brahma, Dewa Wisnu dan Dewa Siwa) secara turun temurun dan mempunyai harta kekayaan yang dikelola secara mandiri oleh desa pakraman itu sendiri melalui perangkat-perangkat adat serta berdasarkan ketentuan-ketentuan hukum adatnya. 
Budiana berpandangan bahwa dalam dinamika kehidupannya, desa pakraman telah tumbuh bahkan berkembang dengan baik pada segala aspek kehidupannya, yang dikelola atas dasar hak otonomi yang telah diwarisi secara turun temurun (Budiana, 2011).

Salah satu bentuk otonomi desa pakraman adalah mengatur dan mengelola peruntukkan harta kekayaan desa pakraman. Harta kekayaan desa pakraman dapat berupa benda bergerak maupun tidak bergerak, berupa tanah adat atau tanah ulayat. Tanah ulayat dari desa pakraman ini merupakan bagian dari tanah adat yang membutuhkan pengakuan dan perlindungan hukum serta kepastian hukum. Hal tersebut disebabkan karena kedudukan dan fungsi dari tanah ulayat bagi masyarakat hukum adat di Bali sangat strategis. Budiana menyoroti bahwa kaitannya dengan pengaturan dan pengelolaan aset desa pakraman berupa setra, tanah laba pura, tanah desa, batas desa dan lain sebagainya yang belum mendapatkan penataan dalam bentuk kepastian hukum dari negara dapat menimbulkan terjadinya sederet permasalahan yang berujung terjadinya konflik-konflik adat (Budiana, 2011). Konflik-konflik adat tersebut tentunya dapat menimbulkan disharmonisasi dan bahkan disintegrasi dalam kehidupan masyarakat hukum adat sebagai bagian dari bangsa Indonesia.

Suasthawa Dharmayuda berpandangan bahwa tanah-tanah adat di Bali mempunyai fungsi yang sangat strategis, yaitu pertama berfungsi ekonomis sebagai sarana pokok dan penunjang dalam kehidupan rumah tangga masyarakat, kedua, tanah adat mempunyai fungsi sosial ke dalam lingkup desa pakraman maupun lingkup kehidupan sosial masyarakat umum semisal digunakan untuk pasar, lapangan dan lain sebagainya, ketiga, tanah adat berperan dalam kehidupan keagamaan di masing-masing desa pakraman (Dharmayuda, 1987). Strategisnya fungsi dari tanah ulayat di Bali, maka sangat diperlukan desa pakraman sebagai kesatuan masyarakat hukum adat, diberikan legal standing sebagai subyek pemegang hak atas tanah adat.

Berdasarkan ketentuan yang diatur dalam peraturan menteri mengenai persyaratan masyarakat hukum adat sebagai pemegang hak komunal atas tanah, sesungguhnya desa pakraman di Bali telah memenuhi persyaratan tersebut. Kedudukan hukum desa pakraman yang dianggap memenuhi persyaratan sebagai subyek pemegang hak komunal atas tanah, dikuatkan dengan dikeluarkannya Keputusan Menteri Agraria dan Tata Ruang/Kepala Badan Pertanahan Nasional Nomor 276/KEP-19.2/X/2017 tentang Penunjukan Desa Pakraman di Provinsi Bali Sebagai Subyek Hak Pemilikan Bersama
(Komunal) Atas Tanah yang selanjutnya dalam tulisan ini disebut dengan surat keputusan.

Desa pakraman di Bali memang layak diberikan legal standing tersebut karena, memang pada dasarnya persyaratan yang diatur dalam peraturan menteri terpenuhi. Persyaratan tersebut terpenuhi secara kumulatif untuk menentukan apakah suatu masyarakat hukum adat dapat diberikan kedudukan hukum sebagai subyek hak komunal atas tanah. Mengacu pada persyaratan pertama, desa pakraman di Bali dapat digolongkan ke dalam masyarakat paguyuban. Ferdinand Tonies menyebutkan bahwa paguyuban merupakan bentuk kehidupan bersama masyarakat dimana anggota-anggotanya diikat dengan adanya hubungan batin yang bersifat murni dan alamiah serta kekal (Susanti \& Sismudjito, 2015).

Anggota-anggota masyarakat dalam suatu desa pakraman mempunyai corak kehidupan bersama yang sangat kental dengan semangat kegotongroyongannya. Disamping itu, mereka diikat dalam suatu hubungan batin dan spiritual serta hidup dalam ruang kehidupan yang sama dengan keinginan dan kewajiban yang sama yaitu, membersihkan desa dari guna kepentingankepentingan yang berkaitan erat dengan kehidupan keagamaannya (Wiryawan, Perbawa \& Wiasta, 2015). Sehingga adanya ikatan satu sama lainnya yang mempunyai rasa lahir dan hidup dalam suatu wilayah yang sama tersebut menjadikan desa pakraman di Bali merupakan masyarakat hukum adat territorial dan keagamaan dengan keyakinan Hindunya.

Atas dasar adanya kehidupan bersama dalam suatu tempat yang sama dan ikatan yang berasal dari hubungan batin tersebut kemudian menjadi dasar bagi masyarakat membangun tatanan kehidupannya. Darwin Ginting menyebutkan masyarakat hukum adat atas dasar kehidupan bersama kemudian membangun peradaban-peradaban tertentu seperti adat-istiadat termasuk tata cara memperoleh dan memanfaatkan tanah, yang kemudian dikenal dengan hak ulayat (Ginting, 2012). Dalam rangka mengatur dan menegakkan peradaban-peradaban yang telah dibangun, tentunya desa pakraman membutuhkan organisasi adat yang bertindak selaku perangkat penguasa adatnya. Perangkat dalam organisasi kekuasaan adat ini di dalam sistem pemerintahan adat disebut sebagai prajuru adat yang dipimpin oleh seorang Bendesa Adat. Prajuru adatlah yang berperan dan berfungsi untuk mengatur kehidupan masyarakat sekaligus menegakkan berbagai peraturan-peraturan adat yang telah dibuat. Termasuk di dalamnya mengatur bagaimana pengaturan, peruntukkan dan pengelolaan tanah-tanah ulayatnya. 
Desa pakraman sendiri mempunyai wilayah hukum adat yang jelas pula batas-batasnya. Batas-batas tersebut lazimnya dituangkan dalam awig-awig sebagai peraturan adat. Wilayah hukum adat yang disebut sebagai palemahan desa pakraman umumnya dibagi ke dalam beberapa banjar pakraman yang merupakan kelompok masyarakat dan menjadi bagian dari desa pakraman. Palemahan tersebut secara normatif diatur pula dalam ketentuan Pasal 4 ayat (2) Perda Desa Pakraman yaitu "Palemahan desa pakraman/banjar pakraman merupakan wilayah kesatuan masyarakat hukum adat yang mempunyai batas-batas tertentu dalam ikatan kahyangan tiga/kahyangan desa.

Membangun peradaban tentunya juga harus diikuti dengan peraturannya yang dapat menjadikan tatanan kehidupan masyarakat menjadi teratur. Demikian pula halnya dengan peradaban yang dibangun oleh desa pakraman tentunya terdapat pranata hukum adatnya yang disebut dengan awig-awig. Budiana berpandangan bahwa setiap desa pakraman membuat awig-awig dengan substansi mengandung prinsip-prinsip yang terkandung dalam konsep Tri Hita Karana dan tidak boleh bertentangan dengan Pancasila, UUD 1945 dan hak asasi manusia. Setelah selesai dirumuskan awig-awig wajib disahkan oleh seluruh krama desa pakraman melalui suatu paruman (rapat) serta setelah disahkan awigawig tersebut dicatatkan di kantor Bupati/Walikota (Budiana, 2011).

Awig-awig sebagai hukum adatnya masyarakat di suatu desa pakraman di Bali berperan sebagai instrumen yang mengatur kehidupan dan interaksi sosial masyarakat. Oleh karena itu, di dalam ketentuan-ketentuannya awigawig mengatur mengenai berbagai hak dan kewajiban anggota masyarakat, kemudian mengatur pula pedoman berprilaku disertai larangan-larangan terhadap suatu prilaku atau tindakan tertentu yang disertai tentunya dengan sanksi-sanksi yang tegas.

Secara kumulatif, persyaratan untuk dapat sebagai subyek hak komunal atas tanah yang dipersyaratkan dalam peraturan menteri telah dipenuhi oleh desa pakraman. Sehingga secara hukum, pengakuan dan perlindungan hukum serta kepastian hukum diharapkan benar-benar dapat diwujudkan terhadap tanah-tanah ulayat yang ada dalam wilayah desa pakraman. Berdasarkan keputusan menteri mengenai penetapan desa pakraman sebagai subyek hak komunal, maka tanah-tanah hak komunal desa pakraman yang dipergunakan untuk keperluan desa pakraman dapat didaftarkan haknya.

Dengan demikian penulis berpandangan bahwa terdapat suatu hubungan kausalitas antara pengakuan eksistensi masyarakat hukum adat khususnya desa pakraman di Bali dengan pengakuan dan perlindungan hukum terhadap tanah-tanah ulayat menuju suatu kepastian hukum. I Nyoman Sirtha memberikan pandangan bahwa desa pakraman mempunyai potensi dan sumber daya guna menunjang tercapainya otonomi daerah yang terlingkup dalam aspek ekonomi, sosial, pemerintahan, budaya, agama dan lain sebagainya yang terintegrasi dalam awig-awig (Sirtha, 2008). Tentunya dengan tercapainya kepastian hukum terhadap keberadaan tanah-tanah ulayat, akan mewujudkan kesejahteraan bersama masyarakat, menjaga keharmonisan kehidupan dan interaksi sosial masyarakat dan dapat memberikan sumbangsih dalam pembangunan daerah. Hal tersebut menjadi suatu faktor penting dewasa ini untuk terus diupayakan.

\section{C.SIMPULAN}

Setelah menguraikan pembahasan mengenai Hak Komunal : Hak Atas Tanah Desa Pakraman di atas, maka dapat disimpulkan bahwa:

1. Hak komunal ini dikonsepkan sebagai model hak atas tanah yang baru dimunculkan dalam sistem hukum tanah nasional. Konsekuensinya adalah masyarakat hukum adat sebagai pemegang hak komunal atas tanah mempunyai kewenangan untuk menggunakan tanahnya untuk keperluan mendirikan bangunan yang berkaitan untuk kepentingan masyarakat hukum adat, serta dapat diambil manfaatnya untuk keperluan pertanian, perkebunan dan peternakan. Penggunaan dan pemanfaatan hak tersebut tetap dilandaskan pada ketentuanketentuan hukum adat yang berlaku di wilayah tersebut. Disamping itu, pemanfaatan dan penggunaan hak komunal atas tanah yang telah didaftarkan, dapat dikerjasamakan dengan pihak ketiga. Tentunya hal tersebut, sesuai dengan kesepakatan yang nantinya disepakati oleh masyarakat hukum adat.

2. Desa pakraman sebagai masyarakat hukum adat, telah memenuhi syarat sebagai pemegang hak komunal atas tanah yaitu desa pakraman di Bali digolongkan ke dalam masyarakat paguyuban, mempunyai sistem pemerintahan adat disebut sebagai prajuru adat yang dipimpin oleh seorang Bendesa Adat. Kemudian desa pakraman mempunyai wilayah hukum adat yang jelas pula batas-batasnya. Wilayah hukum adat yang disebut sebagai palemahan desa pakraman umumnya dibagi ke dalam beberapa banjar pakraman yang merupakan kelompok masyarakat dan menjadi bagian dari desa pakraman. Sebagai instrumen yang mengatur kehidupan dan interaksi sosial masyarakat awig-awig sebagai hukum adatnya masyarakat di suatu desa pakraman di Bali. Oleh karena itu, awig-awig mengatur mengenai 
berbagai hak dan kewajiban anggota masyarakat, kemudian mengatur pula pedoman berprilaku disertai larangan-larangan terhadap suatu prilaku atau tindakan tertentu yang disertai tentunya dengan sanksi-sanksi yang tegas.

\section{Daftar Pustaka}

\section{A.Buku}

Dharmayuda, I Made Suasthawa, 1987, Status dan Fungsi Tanah Adat Bali Setelah Berlakunya UUPA, Denpasar: CV. Kayu Mas.

2001, Desa Adat Kesatuan Masyarakat Hukum Adat di Propinsi Bali, Denpasar: Upada Sastra.

Hadikusuma, Hilman, 2003, Pengantar Ilmu Hukum Adat Indonesia, Bandung: Mandar Maju.

Huda, Ni'Matul, 2015, Ilmu Negara, Jakarta : Rajawali Pers.

Harsono, Boedi, 2005, Hukum Agraria Indonesia Sejarah Pembentukan Undang-Undang Pokok Agraria, Isi dan Pelaksanaannya, Jakarta: Djambatan.

Latif, Abdul \& Hasbi Ali, 2010, Politik Hukum, Jakarta : Sinar Grafika.

Mahfud MD, Moh, 2012, Politik Hukum di Indonesia, Jakarta : Rajawali Pers.

Rosadi, Otong \& Andi Desmon, 2013, Studi Politik Hukum Suatu Optik Ilmu Hukum, Yogyakarta : Thafa Media.

Santoso, Urip, 2010, Pendaftaran dan Peralihan Hak Atas Tanah, Jakarta : Kencana.

Santoso, Urip, 2010, Hukum Agraria dan HakHak Atas Tanah, Jakarta : Kencana.

Setiady, Tolib, 2009, Intisari Hukum Adat Indonesia dalam Kajian Pustaka, Bandung: Alfabeta.

Sirtha, I Nyoman, 2008, Aspek Hukum Dalam Konflik Adat di Bali, Denpasar: Udayana University Press.

Sukirno, 2018, Politik Hukum Hak Ulayat, Jakarta : Prenadamedia Group.

Sumardjono, Maria SW, 2009 Kebijakan Pertanahan Antara Regulasi dan Implementasi, Jakarta: Kompas.

Syaukani, Imam \& Ahsin Thohari, 2013, DasarDasar Politik Hukum, Jakarta : Rajawali Pers.

Wiguna, I Gusti Ngurah Tara, 2009, Hak-Hak Atas Tanah Pada Masa Bali Kuna Abad $X$-XI Masehi, Denpasar : Udayana University Press.

\section{B.Artikel Jurnal}

Budiana, INyoman, 2011 : "Memahami Otonomi Desa Pakraman Sebagai Kesatuan Masyarakat Hukum Adat di Bali (Kajian dari PerspektifHirarki Perundang-undangan Indonesia)”, Jurnal Konstitusi, Vol. I, No. 1 .

2011 : "Penataan Asset Dalam Rangka Mencegah Konflik Antar Desa Pakraman di Bali”, Jurnal Hukum Undiknas Denpasar, Vol. 7 No. 2.

Ginting, Darwin, 2012 : "Politik Hukum Agraria Terhadap Hak Ulayat Masyarakat Hukum Adat di Indonesia", Jurnal Hukum dan Pembangunan Tahun ke-42, No.1.

Ismi, Hayatul, 2012 : "Pengakuan dan Perlindungan Hukum Hak Masyarakat Hukum Adat Atas Tanah Ulayat Dalam Upaya Pembaharuan Hukum Nasional", Jurnal Ilmu Hukum, Vol. 2 No. 2.

Mandala, I Gusti Partana, 2011 : "Eksistensi Desa Adat Dalam Penguasaan dan Pemanfaatan TanahAdat di Bali", Jurnal Hukum Undiknas Denpasar, Vol. 7, No. 2.

Nurjaya, I Nyoman, 2014 : "Paradigma Pembangunan Hukum Nasional Dalam Masyarakat Multikultural : Perspektif Antropologi Hukum", Jurnal Hukum Undiknas, Vol. 1 No. 1.

Susanti, Henny dan Sismudjito, 2015 : "Fungsi Ikatan Persaudaraan Muslim Socfindo (IPMS) Dalam Membangun Hubungan Sosial Dengan Masyarakat Sekitar", Jurnal Perspektif Sosiologi, Vol. 3 No.1.

Wiguna, Made Oka Cahyadi, 2016 : "Pengaruh Eksistensi Masyarakat Hukum Adat Terhadap Penguasaan Tanah Prabumian Berdasarkan Konsepsi Komunalistik Religius di Bali", Jurnal Novelty, Vol. 7 No. 2.

Wiryawan, I Wayan Gde, Ketut Sukawati Lanang P. Perbawa, I Wayan Wiasta, 2015 : "Hukum Adat Bali di Tengah Modernisasi Pembangunan dan Arus Budaya Global", Jurnal Baki Saraswati, Vol. 4 No. 2.

\section{C.Website}

http://www.aman.or.id/profil-aliansi-masyarakatadat-nusantara/, diakses 7 Agustus 2018, Pukul 11.18

https://www.beritabali.com/read/2017/12/08/ 201712080017/Tahun-2017-MajelisUtama-Desa-Pakraman-Bali-Kukuhkan-5DP-Baru-Salah-Satunya-di-Tabanan.html, Majelis Utama Desa Pakraman Bali Kukuhkan 5 Desa Pakraman Baru, Salah Satunya di Tabanan, diakses tanggal 3 Juli 2017, pukul 10.54. 